\title{
Implementasi Model Pembelajaran Inkuiri Terbimbing pada Pokok Bahasan Suhu Dan Kalor di Kelas VII SMP
}

\author{
Implementation of Guided Inquiry Learning Model on Subjects of \\ Temperature and Heat in Class VII of Junior High School
}

\author{
Sulistiyani ${ }^{1 *}$, Gunarjo S. Budi ${ }^{2}$, Dr. Enny Wijayanti ${ }^{3}$, Pri Ariadi Cahya \\ Dinata $^{4}$ \\ 1,2,3,4 Pendidikan Fisika, Fakultas Keguruan dan Ilmu Pendidikan, \\ Universitas Palangka Raya, Palangka Raya - Indonesia 73111 \\ *E-mail: sulistiyani417@gmail.com
}

\begin{abstract}
Abstrak
Penelitian ini bertujuan meningkatkan keterampilan psikomotor dan hasil belajar kognitif siswa setelah diterapkan model pembelajaran inkuiri terbimbing. Jenis penelitian adalah Pre-Experimental dengan desain one-shot case study. Populasi penelitian adalah seluruh kelas VII semester I SMP Negeri 2 Palangka Raya tahun ajaran 2018/2019 yang berjumlah 11 kelas. Sampel yang diambil dengan teknik random sampling. Sampel dalam penelitian ini adalah kelas VII-10 dengan jumlah 32 siswa. Data dikumpulkan menggunakan: (1) instrumen keterampilan psikomotor; (2) instrumen tes hasil belajar kognitif. Hasil penelitian yang diperoleh adalah: (1) keterampilan psikomotor peserta didik meningkat untuk tiap pelaksanaan pembelajaran; (2) ketuntasan hasil belajar kognitif siswa secara individu dari 32 siswa diperoleh 25 siswa tuntas dan 7 siswa tidak tuntas. Hasil ini menujukkan bahwa model pembelajaran inkuiri terbimbing dapat meningkatkan keterampilan psikomotor dan hasil belajar kognitif siswa..
\end{abstract}

Kata kunci: Pembelajaran inkuiri terbimbing, keterampilan psikomotor siswa, hasil belajar kognitif siswa.

\begin{abstract}
The research aims to improve students' psychomotor skills and cognitive learning outcomes after the guided inquiri learning model is applied. This type of research is PreExperimental with one-shot case study design. The research population is all grade VII in one of junior high schools in Palangka Raya, which amounts to 11 classes. Samples taken with random sampling techniques. The sample in this study was grades VII-10 with a total of 32 students. Data were collected by psychomotor skill instruments and cognitive learning test instruments. The results of the research obtained are: (1) the psychomotor skills of learners increased for each implementation of learning; (2) 25 students of 32 have passed the exam passing grade to determine their learning outcomes. These results show that guided learning models can improve students' psychomotor skills and cognitive learning outcomes.
\end{abstract}

Keywords: Guided Inquiry Learning model, psychomotor skills, cognitive learning outcomes. 


\section{PENDAHULUAN}

Pendidikan merupakan proses agar siswa memiliki kekuatan spiritual, pengendalian diri, kepribadian, kecerdasan, akhlak mulia, serta keterampilan dalam bermasyarakat, berbangsa dan bernegara (Jufri, 2013: 39). Berdasarkan pendapat ahli di atas disimpulkan bahwa pendidikan merupakan proses perubahan yang dilakukan dalam bentuk usaha untuk menumbuhkan segala potensi yang dimiliki oleh siswa agar mendapatkan lulusan yang mampu bersaing pada era globalisasi dan siap bekerja secara mandiri.

Berdasarkan hasil observasi dan wawancara yang dilaksanakan peneliti di SMP Negeri 2 Palangka Raya, ditemukan bahwa pembelajaran IPA disekolah tersebut lebih ditekankan kepada aspek kognitif. Hasil KKM menunjukkan rata-rata hasil ulangan terhadap materi kalor disajikan pada Tabel 1 dengan KKM 75. Siswa tidak dilatih bagaimana merumuskan hipotesis, melakukan percobaan, menganalisis data, dan menyusun kesimpulan dalam percobaan. Keterampilan dalam melakukan percobaan atau eksperimen di laboratorium jarang dilakukan sehingga keterampialan psikomotor siswa kurang baik. Percobaan di laboratorium dilakukan di kelas XII menjelang ujian praktek.

Siswa juga sangat jarang melakukan kegiatan percobaan sehingga keterampilan psikomotor tidak pernah dinilai menggunakan rubrik penilaian sehigga berdampak pada psikomotor siswa rendah dan mempengaruhi hasil belajar kognitif siswa. Keterampilan motorik membantu siswadalam memahami konsep yang sedang dipelajari. Pernyataan tersebut diperkuat dengan hasil belajar kognitif siswa masih terdapat beberapa yang berada dibawah nilai Kriteria Ketuntasan Minimal (KKM) sekolah tersebut yaitu sebesar 75 untuk IPA.

Nilai rata-rata hasil ulangan harian materi suhu dan kalor siswa kelas VII semester I pada tahun ajaran 2017/2018 disajikan pada Tabel 1.

Tabel 1. Nilai Rata-rata Ulangan Harian Mata Pelajaran IPA Kelas VII Tahun Ajaran 2017/2018

\begin{tabular}{|c|c|}
\hline Kelas & Nilai Rata-rata \\
\hline VII-1 & 63 \\
\hline VII-2 & 60 \\
\hline VII-3 & 71 \\
\hline VII-4 & 67 \\
\hline VII-5 & 69 \\
\hline VII-6 & 70 \\
\hline VII-7 & 71 \\
\hline VII-8 & 70 \\
\hline VII-9 & 70 \\
\hline VII-10 & 69 \\
\hline VII-11 & 69 \\
\hline
\end{tabular}

Berdasarkan tabel di atas, terlihat bahwa nilai rata-rata belajar siswa pada materi suhu dan kalor kelas VII SMP Negeri 2 Palangka Raya tahun ajaran 2017/2018, masih tergolong rendah karena tidak mencapai KKM (tidak Tuntas), hal ini disebebkan karena pembelajaran IPA yang dilaksanakan masih banyak menggunakan metode ceramah. Metode ceramah adalah metode yang digunakan guru dalam mengajar. Metode ini membuat siswa menjadi tidak aktif karena mengangap guru sebagai satu-satunya sumber informasi dalam pembelajaran. Konsep yang telah diterima oleh siswa hanya sebatas teoritis atau tekstual, tetapi siswa tidak melakukan percobaan 
untuk menemukan konsep tersebut sehingga menyebabkan rendahnya keterampilan psikomotor siswa. Siswa tidak mendapatkan pengalaman kerja laboratorium. Hal ini membuat pembelajaran IPA dianggap membosankan karena membuat siswa menjadi tidak aktif untuk melakukan diskusi dan selain itu membuat siswa merasa jenuh mengikuti pembelajaran IPA dari awal sampai berakhir pembelajaran. Pembelajaran yang menyenangkan adalah pembelajaran yang dapat diikuti siswa. Pembelajaran yang menyenangkan memberikan tantangan kepada siswa untuk berpikir, mencoba dan belajar lebih lanjut untuk mengembangkan kemampuan diri (Jauhar, 2011: 164).

Menurut Sanjaya (2011:200) pembelajaran inkuiri yaitu suatu model pembelajaran inkuiri yang dalam pelaksanaannya guru menyediakan bimbingan atau petunjuk cukup luas kepada siswa. Pembelajaran inkuiri terbimbing guru tidak melepas begitu saja kegiatan-kegiatan yang dilakukan oleh siswa. Guru harus memberikan pengarahan dan bimbingan kepada siswa dalam melakukan kegiatan-kegiatan.

Materi kalor mempunyai kompetensi dasar yaitu melakukan percobaan untuk menyelidiki pengaruh kalor terhadap suhu dan wujud benda serta perpindahan kalor. Model inkuiri terbimbing sangat relevan digunakan karena pada materi ini siswa sangat berperan langsung dalam menemukan hasil dari percobaan dalam kelompok.

Berdasarkan uraian di atas, maka tujuan Tujuan penelitian ini adalah: (1) mengetahui keterampilan psikomotor siswa setelah penerapan model pembelajaran inkuiri terbimbing. (2) Mengetahui ketuntasan hasil belajar kognitif siswa setelah menggunakan model pembelajaran inkuiri terbimbing pada materi suhu dan kalor.

\section{BAHAN DAN METODE}

Desan penelitian ini merupakan Pra-Experimental karena desain ini belum merupakan eksperimen sungguh-sungguh sebab masih terdapat variabel luar yang mempengaruhi eksperimen (Sugiyono, 2012:110). Rancangan yang digunakan yaitu One-Shot Case Study terdapat suatu kelompok diberi perlakuan, dan selanjutnya diobservasi hasilnya (Sugiyono, 2012: 112).

Populasi dalam penelitian ini adalah seluruh kelas VII di SMP Negeri 2 Palangka Raya yang terdiri atas 11 kelas. Adapun sebaran kelas sebagai berikut:

Tabel 2. Sebaran Populasi Penelitian

\begin{tabular}{|c|c|}
\hline Kelas & Jumlah Siswa \\
\hline VII-1 & 32 \\
\hline VII-2 & 30 \\
\hline VII-3 & 32 \\
\hline VII-4 & 31 \\
\hline VII-5 & 32 \\
\hline VII-6 & 31 \\
\hline VII-7 & 32 \\
\hline VII-8 & 30 \\
\hline VII-9 & 32 \\
\hline VII-10 & 32 \\
\hline VII-11 & 32 \\
\hline TOTAL & 346 siswa \\
\hline
\end{tabular}


Sampel dalam penelitian ini sebanyak 1 kelas. Pemilihan sampel penelitian dilakukan secara acak (random sampling) yaitu dengan melakukan undian terhadap semua kelas populasi yang akan dijadikan sebagai kelas sampel dengan asumsi seluruh kelas homogen. Setelah diundi diperoleh sampel yaitu kelas VII-10 dengan jumlah siswa 32 orang.

Penelitian ini menggunakan 2 (dua) jenis instrumen dalam mengumpulkan data, yaitu:

1. Lembar pengamatan psikomotor yang berupa penilaian keterampilan siswa melakukan percobaan pada materi suhu dan kalor yang dilaksanakan selama pembelajaran berlangsung.

2. Tes hasil belajar (THB) kognitif dalam bentuk pilihan ganda sebanyak 32 soal pilihan ganda untuk mengukur hasil belajar kognitif.

Teknik analisis penilaian keterampilan psikomotor merupakan penilaian kompetensi keterampilan adalah penilaian yang dilakukan pendidik untuk mengukur tingkat pencapaian kopetensi keterampilan dari siswa yaitu meliputi aspek moving, manipulating, comunicating (Supriatiningrum, 2013: 241). Rumus untuk menghitung nilai keterampilan psikomotor kelompok adalah sebagai berikut (Kunandar, 2014: 270):

Nilai $=\frac{\text { total skor yang diperoleh }}{\text { skor maksimum }} \times 100 \%$

Kriteria penilaian keterampilan kelompok yaitu: interval 91 sampai 100 kategori sangat baik, 71 sampai 90 baik, 61 sampai 70 cukup dan $\leq 61$ kurang.

Teknik Analisis Data Tes Hasil Belajar (THB). Standar ketuntasan belajar individu ranah pengetahuan yang ditetapkan SMP Negeri 2 Palangka Raya adalah $\geq 75$. Ketuntasan individu dianalisis dengan menggunakan rumus berikut (Trianto, 2010: 241)

$K B=\left[\frac{\text { Jumlah Skor peserta didik }}{\text { Jumlah skor total }}\right] \times 100 \%$

Ketuntasan belajar secara klasikal dikatakan tuntas jika dalam kelas tersebut terdapat $\geq 75 \%$ siswa yang telah tuntas dari jumlah seluruh siswa. Ketuntasan klasikal menurut Trianto (2010: 241) dapat dihitung menggunakan rumus sebagai berikut:

$K K=\left[\frac{\text { Banyaknya siswa yang tuntas }}{N}\right] \times 100 \%$

Satu TPK tuntas apabila persentase (P) siswa yang mencapai TPK tersebut $\geq 75 \%$, untuk menghitung ketuntasan TPK rumus persentasenya adalah (Purwanto, 2012: 103):

$N_{T P K}=\left[\frac{P_{T p k}}{P_{S}}\right] \times 100 \%$

Keterangan:

$N_{T P K} \quad=$ Nilai persentase ketuntasan belajar klasikal siswa

$P_{T p k} \quad=$ Jumlah siswa yang tuntas belajar

$P_{S} \quad=$ Jumlah seluruh siswa

\section{HASIL}

Penelitian ini dilaksanakan mulai hari Selasa tanggal 28 November 2018 untuk RPP I, 29 November 2018 untuk RPP II , 30 November 2018 untuk RPP III, dan tanggal 3 Desember 2019 melakukan tes hasil belajar (THB) di SMP Negeri 2 Palangka Raya. 
Analisis data Keterampilan psikomotor pada proses pembelajaran RPP I di sajikan pada Tabel 3.

Tabel 3. Rekapitulasi nilai Keterampilan Psikomotor pada pertemuan I, II dan III

\begin{tabular}{|c|c|c|c|c|c|}
\hline Pertemuan & Kelompok & $\begin{array}{c}\text { Percobaan } \\
\text { ke }\end{array}$ & Skor & Nilai (\%) & Kategori \\
\hline \multirow{4}{*}{$\mathrm{Ke}-1$} & 1 & I & 23 & $82,14 \%$ & Baik \\
\hline & 2 & I & 26 & $92,85 \%$ & Sangat baik \\
\hline & 3 & I & 26 & $92,85 \%$ & Sangat baik \\
\hline & 4 & I & 25 & $89,28 \%$ & Baik \\
\hline \multirow{8}{*}{$\mathrm{Ke}-2$} & \multirow[t]{2}{*}{1} & $\mathrm{I}$ & 31 & $77,5 \%$ & Cukup Baik \\
\hline & & II & 33 & $82,5 \%$ & Baik \\
\hline & \multirow[t]{2}{*}{2} & I & 31 & $77,5 \%$ & Cukup Baik \\
\hline & & II & 31 & $77,5 \%$ & Cukup Baik \\
\hline & \multirow[t]{2}{*}{3} & I & 33 & $82,50 \%$ & Baik \\
\hline & & II & 31 & $77,5 \%$ & Cukup Baik \\
\hline & \multirow[t]{2}{*}{4} & I & 30 & $75 \%$ & Baik \\
\hline & & II & 30 & $75 \%$ & Cukup Baik \\
\hline \multirow{12}{*}{$\mathrm{Ke}-3$} & \multirow[t]{3}{*}{1} & I & 24 & $85,71 \%$ & Baik \\
\hline & & II & 25 & $89,28 \%$ & Baik \\
\hline & & III & 25 & $89,28 \%$ & Baik \\
\hline & \multirow[t]{3}{*}{2} & I & 20 & $71,43 \%$ & Cukup Baik \\
\hline & & II & 28 & $100 \%$ & Sangat baik \\
\hline & & III & 27 & $96,43 \%$ & Sangat baik \\
\hline & \multirow[t]{3}{*}{3} & I & 24 & $85,71 \%$ & Baik \\
\hline & & II & 23 & $82,14 \%$ & Baik \\
\hline & & III & 25 & $89,28 \%$ & Baik \\
\hline & \multirow[t]{3}{*}{4} & $\mathrm{I}$ & 23 & $82,14 \%$ & Baik \\
\hline & & II & 23 & $82,14 \%$ & Baik \\
\hline & & III & 25 & $89,28 \%$ & Baik \\
\hline \multicolumn{4}{|c|}{ Nilai rata-rata } & $84,68 \%$ & Baik \\
\hline
\end{tabular}

Tabel 4. Data Hasil Keterampilan Psikomotor setiap komponen

\begin{tabular}{|c|c|c|c|c|c|c|}
\hline Pertemuan & $\begin{array}{l}\text { Keterampilan yang } \\
\text { diamati }\end{array}$ & Komponen & $\begin{array}{c}\text { Percobaan } \\
\mathrm{Ke}\end{array}$ & $\begin{array}{c}\text { Jumlah } \\
\text { Skor Per } \\
\text { Komponen }\end{array}$ & $\begin{array}{l}\text { Nilai Rata- } \\
\text { rata per } \\
\text { Komponen }\end{array}$ & Keterangan \\
\hline \multirow{3}{*}{$\mathrm{Ke}-1$} & $\begin{array}{c}\text { Melakukan percobaan } \\
\text { (Moving) }\end{array}$ & P1 & I & 44 & $91,66 \%$ & Sangat baik \\
\hline & $\begin{array}{c}\text { Menganalisis Data } \\
\text { (Manipulating) }\end{array}$ & $\mathrm{P} 2$ & I & 27 & $84,37 \%$ & Baik \\
\hline & $\begin{array}{l}\text { Membuat Kesimpulan } \\
\text { (Communicating) }\end{array}$ & P3 & I & 29 & $90,62 \%$ & Sangat baik \\
\hline \multirow{6}{*}{$\mathrm{Ke}-2$} & \multirow{2}{*}{$\begin{array}{c}\text { Melakukan percobaan } \\
\text { (Moving) }\end{array}$} & \multirow{2}{*}{ P1 } & $\mathrm{I}$ & 48 & $75 \%$ & Cukup baik \\
\hline & & & II & 56 & $87,50 \%$ & Cukup baik \\
\hline & \multirow{2}{*}{$\begin{array}{c}\text { Menganalisis Data } \\
\text { (Manipulating) }\end{array}$} & \multirow{2}{*}{$\mathrm{P} 2$} & $\mathrm{I}$ & 40 & $83,33 \%$ & Baik \\
\hline & & & II & 39 & $81,25 \%$ & Baik \\
\hline & \multirow[b]{2}{*}{$\begin{array}{c}\text { Membuat Kesimpulan } \\
\text { (Communicating) }\end{array}$} & \multirow[b]{2}{*}{ P3 } & I & 36 & $75,00 \%$ & Cukup baik \\
\hline & & & II & 38 & $79,16 \%$ & Cukup baik \\
\hline \multirow{9}{*}{$\mathrm{Ke}-3$} & \multirow{3}{*}{$\begin{array}{c}\text { Melakukan percobaan } \\
\text { (Moving) }\end{array}$} & \multirow{3}{*}{ P1 } & I & 50 & $78,13 \%$ & Cukup baik \\
\hline & & & II & 56 & $87,50 \%$ & Baik \\
\hline & & & III & 59 & $92.19 \%$ & Baik \\
\hline & \multirow{3}{*}{$\begin{array}{c}\text { Menganalisis Data } \\
\text { (Manipulating) }\end{array}$} & \multirow{3}{*}{$\mathrm{P} 2$} & I & 16 & $100 \%$ & Sangat baik \\
\hline & & & II & 13 & $81,13 \%$ & Baik \\
\hline & & & III & 15 & $93,75 \%$ & Baik \\
\hline & \multirow{3}{*}{$\begin{array}{l}\text { Membuat Kesimpulan } \\
\text { (Communicating) }\end{array}$} & \multirow{3}{*}{ P3 } & I & 25 & $78,13 \%$ & Cukup baik \\
\hline & & & II & 30 & $93,75 \%$ & Sangat baik \\
\hline & & & III & 28 & $87,50 \%$ & Sangat baik \\
\hline \multicolumn{5}{|c|}{ Nilai Rata-rata } & $84,33 \%$ & Baik \\
\hline
\end{tabular}

Tabel 5. data hasil keterampilan psikomotor tiap aspek 


\begin{tabular}{|c|c|c|c|c|c|c|c|c|c|}
\hline \multirow{2}{*}{ Pertenual } & \multirow{2}{*}{$\begin{array}{c}\text { Rerubian } \\
\text { he }\end{array}$} & \multirow{2}{*}{ Aspek } & \multicolumn{4}{|c|}{ helompok } & \multirow{2}{*}{ Swor } & \multirow{2}{*}{ Nilai } & \multirow{2}{*}{ Kategui } \\
\hline & & & 1 & 2 & 3 & 4 & & & \\
\hline \multirow{7}{*}{$\mathrm{Ke}-1$} & \multirow{7}{*}{$\rrbracket$} & I & 1 & 4 & 4 & 4 & 14 & $875 \%$ & Hail \\
\hline & & 2 & 4 & 4 & 4 & 4 & 15 & $93,75 \%$ & Sangat Baik \\
\hline & & 1 & 3 & 4 & 4 & 3 & 14 & 975 & Hail \\
\hline & & 4 & 4 & 4 & 3 & 4 & 15 & $93,75 \%$ & Sungat Bail \\
\hline & & 5 & 3 & 3 & 3 & 3 & 12 & $75 \mathrm{~h}$ & Cunup Balk \\
\hline & & $b$ & 3 & 3 & 4 & 3 & $1 \frac{5}{3}$ & $81,25 \%$ & Hail \\
\hline & & 7 & 4 & 4 & 4 & 4 & 16 & $100 \%$ & Sangat Baik \\
\hline \multirow{20}{*}{$\mathrm{ke}=2$} & \multirow{10}{*}{ 】 } & 】 & 1 & 4 & 2 & 3 & 11 & $43,75 \%$ & Kung Balk \\
\hline & & 2 & 4 & 3 & 4 & 4 & 15 & 68,75 क & Sangat Baik \\
\hline & & 3 & 1 & 3 & 3 & $\frac{13}{3}$ & $\pi$ & $68,75 \%$ & Kunang Bails \\
\hline & & 4 & 3 & 3 & 3 & 3 & 12 & $75 \%$ & Cusup Balk \\
\hline & & 5 & 4 & 4 & 3 & 4 & 15 & $93,75 \%$ & Sungat Baik \\
\hline & & $\bar{b}$ & 3 & 4 & 3 & 3 & $1 \frac{13}{3}$ & $81,25 \%$ & Haik \\
\hline & & 7 & 3 & 3 & 3 & 3 & 11 & 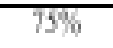 & Cunup Baik \\
\hline & & 8 & 4 & 2 & 4 & 3 & $1 \frac{15}{3}$ & $91,25 \%$ & Hail \\
\hline & & 9 & 1 & 2 & 4 & 2 & 10 & $615 \mathrm{~m}$ & Kung Baik \\
\hline & & 10 & 4 & 3 & 4 & 2 & 13 & $9 L, 25 \%$ & Haik \\
\hline & \multirow{10}{*}{ II } & I & 1 & 2 & 3 & 3 & 10 & $81,25 \%$ & Kung Bails \\
\hline & & 2 & 4 & 3 & 3 & $\frac{3}{3}$ & 13 & $619 \%$ & Hail \\
\hline & & 3 & 1 & 3 & 3 & 3 & $\pi$ & $68,75 \%$ & Kung Baik \\
\hline & & 4 & 3 & 4 & 3 & 2 & 12 & $75 \%$ & Cunpp Baik \\
\hline & & 5 & 4 & 3 & 3 & 3 & 13 & $81,25 \%$ & Hail: \\
\hline & & $b$ & 3 & 3 & 4 & 3 & 13 & $81,25 \%$ & Hail \\
\hline & & 7 & 4 & 3 & 3 & 3 & 15 & $81,25 \%$ & Hail: \\
\hline & & $\mathrm{s}$ & 4 & 4 & 2 & 4 & 14 & $875 \%$ & Hail: \\
\hline & & 9 & 1 & 3 & 4 & 3 & 11 & $75 \%$ & Cunup Baik \\
\hline & & 10 & 3 & 3 & 3 & $\frac{3}{3}$ & 11 & $75 \mathrm{~W}$ & Cunup Bnil: \\
\hline \multirow{21}{*}{$\mathrm{Ke}_{-3}$} & \multirow{7}{*}{ I } & I & 2 & 1 & 2 & 2 & 7 & $100 \%$ & Kung Balk \\
\hline & & 2 & 4 & 4 & 4 & 4 & 16 & $43,75 \mathrm{~T}$ & Sangat Baik \\
\hline & & 3 & 3 & 3 & 3 & 3 & 12 & $75 \%$ & Cunup Baik \\
\hline & & 4 & 4 & 3 & 4 & 4 & 13 & $43,75 \%$ & Sanagt Baik \\
\hline & & 5 & 4 & 4 & 4 & 4 & 16 & $100 \%$ & Sungat Buik \\
\hline & & $b$ & 3 & 2 & 3 & 3 & $\pi$ & $68.75 \%$ & Kung Bals \\
\hline & & 7 & 4 & 3 & 4 & 3 & 14 & 8794 & Hail \\
\hline & \multirow{7}{*}{ II } & I & 3 & 4 & 2 & 2 & II & $100 \%$ & Kurang Baik \\
\hline & & 2 & 4 & 4 & 4 & 4 & 16 & $69.75 \%$ & Sungat Baik \\
\hline & & 3 & 4 & 4 & 3 & 3 & 14 & $875 \%$ & Hail: \\
\hline & & 4 & 4 & 4 & 4 & 3 & 15 & $93,75 \%$ & Sanat Balk \\
\hline & & 5 & 3 & 4 & 3 & 3 & 15 & $91,25 \%$ & Hail: \\
\hline & & $b$ & 3 & 4 & 3 & 4 & 14 & $973+4$ & Hail: \\
\hline & & 7 & 4 & 4 & 4 & 4 & 16 & $100 \%$ & Sangat Baik \\
\hline & \multirow{7}{*}{ IIII } & I & 3 & 4 & 2 & 2 & 11 & $100 \%$ & Sangat Baik \\
\hline & & 2 & 4 & 4 & 4 & 4 & 16 & $68,75 \%$ & Sangat Baik \\
\hline & & 3 & 4 & 4 & 4 & 4 & 16 & $100 \%$ & Sangat Baik \\
\hline & & 4 & 4 & 4 & 4 & 4 & 16 & $100^{2}$ & Sangat Baik \\
\hline & & 5 & 3 & 4 & 4 & 4 & 13 & $4,75 \%$ & Sangat Baik \\
\hline & & 6 & 3 & 3 & 3 & 3 & 12 & 75, & Cusup Balk \\
\hline & & 7 & 4 & 4 & 4 & 4 & 16 & $100 \%$ & Sangat Baik \\
\hline
\end{tabular}

Ketuntasan individu dan klasikal setelah mengikuti pembelajaran dengan pembelajaran model inkuiri terbimbing pada materi suhu dan kalor disajikan dalam Tabel 7. 
Tabel 7. Ketuntasan Hasil Belajar Individu dan Klasikal Siswa

\begin{tabular}{|l|c|}
\hline \multicolumn{1}{|c|}{ Ketuntasan } & Jumlah Siswa \\
\hline Tuntas & 25 \\
\hline Tidak Tuntas & 7 \\
\hline Ketuntasan Klasikal (\%) & $78,12 \%$ \\
\hline
\end{tabular}

Ketuntasan individu dari 32 siswa mengikuti tes diperoleh sebanyak 25 siswa yang tuntas dan 7 siswa yang tidak tuntas. Secara klasikal ketuntasan siswa sebesar $78,12 \%$, dinyatakan tuntas karena mencapai kriteria ketuntasan klasikal yang telah ditetapkan yaitu $\geq 75 \%$.

Ketuntasan TPK. Tujuan pembelajaran khusus (TPK) pada materi suhu dan kalor adalah sebanyak 32 TPK. Hasil analisis ketuntasan TPK terdapat 24 TPK tuntas dan 8 TPK tidak tuntas. Persentase ketuntasan TPK adalah 75\% TPK tuntas dan $25 \%$ TPK tidak tuntas.

\section{PEMBAHASAN}

Hasil keterampilan psikomotor tuiap kelompok untuk tiap RPP disajikan pada Gambar 1.

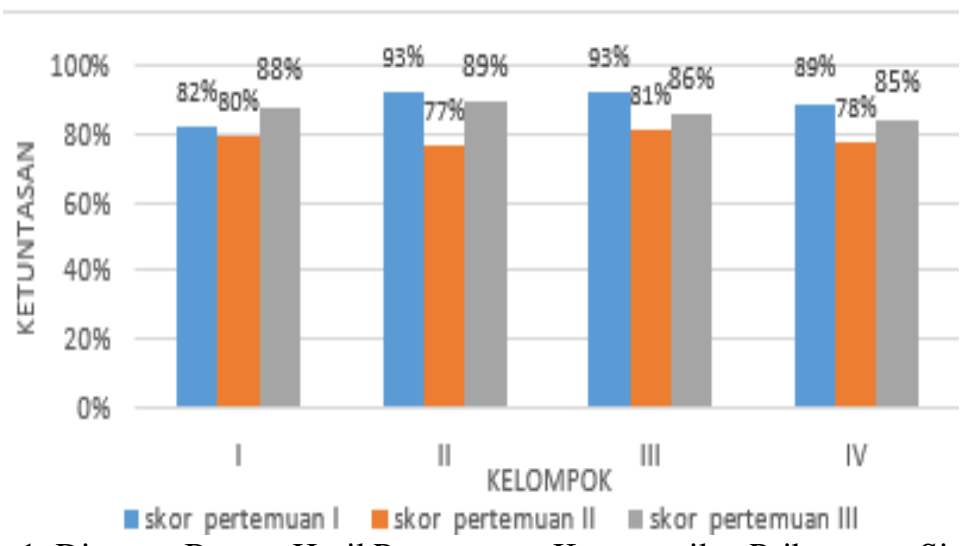

Gambar 1. Diagram Batang Hasil Pengamatan Keterampilan Psikomotor Siswa tiap Kelompok

Gambar 1 menunjukkan nilai psikomotor yang diperoleh tiap kelompok pada pertemuan ke-1, pertemuan ke-2 dan pertemuan ke-3. Masing-masing anggota kelompok memiliki perbedaan dalam berinteraksi sosial dan kemampuan dalam menggunakan alat hal tersebut mempengaruhi perolehan skor masing-masing kelompok.

Pada pertemuan ke-1 mengenai suhu dan perubahannya merupakan hari pertama melakukan percobaan dan sebagian kelompok masih terlihat bingung dalam mengikuti prosedur kerja serta melakukan percobaan. Hal ini dapat terlihat dari diagram yang disajikan dan terlihat jelas pada kelompok I yang merupakan kelompok yang masuk dalam ketegori baik dengan perolehan skor $23(82,14 \%)$. Perolehan skor tersebut dikarenakan siswa masih kesulitan di beberapa langkah kegiatan seperti menggunakan alat praktikum, menganalisis dan menyimpulkan hasil kegiatan, siswa masih perlu dibimbing dan diarahkan oleh guru dan pengamat dalam melakukan kegiatan praktikum. Pada saat melakukan percobaan siswa masih kebingungan dalam membaca skala pada termometer sehingga perlu dibimbing oleh guru dan pengamat. Permasalahan seperti ini terjadi dimungkinkan karena beberapa faktor diantaranya siswa tidak pernah mengguankan termometer. 
Pada pertemuan ke-2 dengan melakukan percobaan mengenai kalor. Ditinjau dari perolehan skor masing-masing kelompok pada pertemuan ke2 terdapat kelompok yang mengalami penurunan perolehan skor kelompok. penurunan perolehan skor kelompok pada pertemuan ke-2 dapat terlihat pada gambar 9, hal ini terlihat jelas pada kelompok I yang termasuk ke dalam kriteria cukup baik dengan perolehan skor $(77,5 \%)$. perolehan skor tersebut dikarenakan sebagian kelompok siswa sedikit kebingungan dalam mengikuti langkah kerja dan merangkai alat percobaan kalor sesuai dengan lembar kerja siswa (LKS). Permasalahan seperti ini terjadi dimungkinkan karena beberapa faktor diantaranya siswa tidak benar-benar dalam membaca lembar kerja siswa (LKS) yang sudah diberikan sebagai pedoman melakukan percobaan. Siswa sedikit kesulitan dalam menganalisis data hasil percobaan sehingga cenderung lama dalam mengerjakannya. Permasalahan seperti ini terjadi dimungkinkan karena beberapa faktor diantaranya siswa yang ada dalam kelompok tersebut kurang memahami akan materi kalor.

Pada pertemuan ke-3 dengan melakukan percobaan mengenai perpindahan kalor. Pada pertemuan ke-3 ini diikuti 31 siswa yang bergabung dalam 4 kelompok, 1 siswa tidak hadir. Ditinjau dari perolehan skor masing-masing kelompok pada pertemuan ke-3 setiap kelompok yang mengalami kenaikan perolehan skor kelompok. Kenaikan perolehan skor kelompok pada pertemuan ke-3 dapat terlihat pada gambar 9, hal ini terlihat jelas pada kelompok I yang termasuk ke dalam kriteria baik dengan perolehan skor $24.6(88,09 \%)$. Perolehan skor tersebut dikarenakan siswa telah mengambil alat dan bahan dengan tepat serta mengikuti prosedur kerja dengan cukup baik.

Hasil pengamatan keterampilan psikomotor tiap aspek untuk semua kelompok pada pertemuan I dapat dilihat pada Gambar 2.

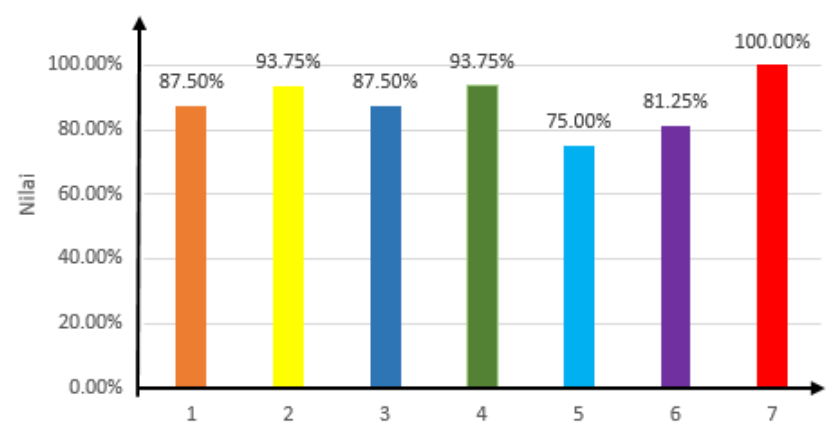

Gambar 2. Diagram Batang Keterampilan psikomotor tiap aspek untuk semua kelompok pada Pertemuan I

Pada pertemuan I aspek yang mendapatkan nilai tertinggi sebesar 100\% yaitu aspek meyimpulkan hasil percobaan sedangkan aspek yang mendapatkan nilai terendah sebesar $75 \%$ kategori cukup baik adalah aspek 5 adalah Ketepatan dalam mengukur suhu air didalam gelas dengan menggunakan termometer

Aspek 7 mendapatkan nilai tertinggi dikarenakan pada aspek ini siswa dapat menyimpulkan hasil percobaan dengan baik siswa mampu menyimpulkan bahwa pengukuran suhu menggunakan termometer lebih akurat dibandingkan menggunakan tangan. 
Aspek 5 mendapatkan nilai terendah dikarenakan pada aspek ini secara umum siswa masih kebingungan dalam membaca skala termometer dan harus dengan bimbingan guru.

Hasil Pengamatan keterampilan psikomotor tiap aspek untuk semua kelompok pada pertemuan II percobaan 1 dapat dilihat pada Gambar 3.

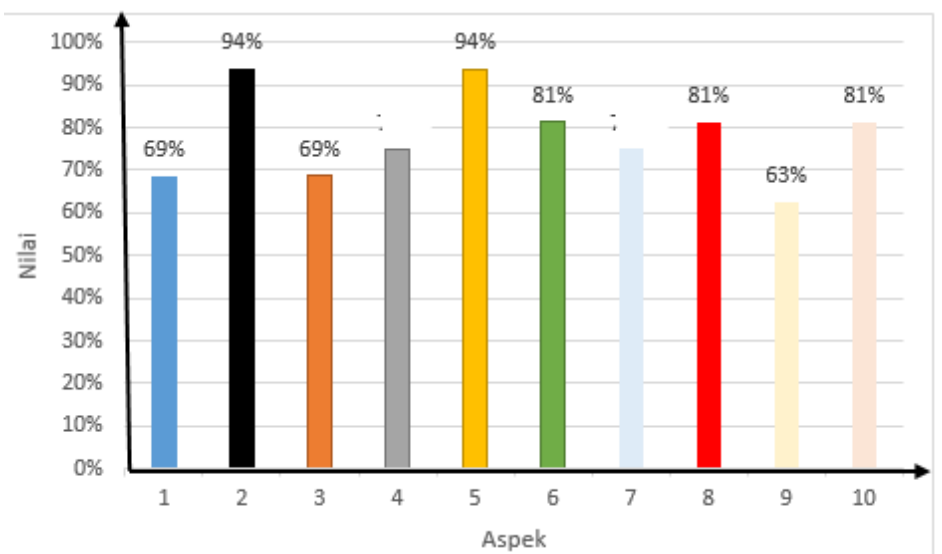

Gambar 3. Diagram Batang Keterampilan psikomotor tiap aspek untuk semua kelompok pada Pertemuan II percobaan 1

Pada pertemuan II percobaan 1 aspek nomor 2 dan 5 sebagai aspek tertinggi yaitu $93,75 \%$ dengan kategori sangat baik. Faktor yang menyebabkan aspek nomor 2 dan 5 memperoleh skor tertinggi karena siswa sudah mengenali alat dan bahan yang akan digunakan dan dapat memasukan air dengan volume $50 \mathrm{~mL}$ dan $100 \mathrm{~mL}$ kedalam gelas beker dengan benar.

Aspek nomor 9 menjadi aspek yang memperoleh skor terendah yaitu $62,5 \%$ dengan kategori kurang baik. Faktor yang menyebabkan aspek nomor 9 pada RPP 2 memperoleh skor terendah adalah siswa masih kesulitan menguji hipotesis dari hasil percobaan yang diperoleh.

Hasil Pengamatan keterampilan psikomotor tiap aspek untuk semua kelompok pada pertemuan II percobaan 2 dapat dilihat pada Gambar 4.

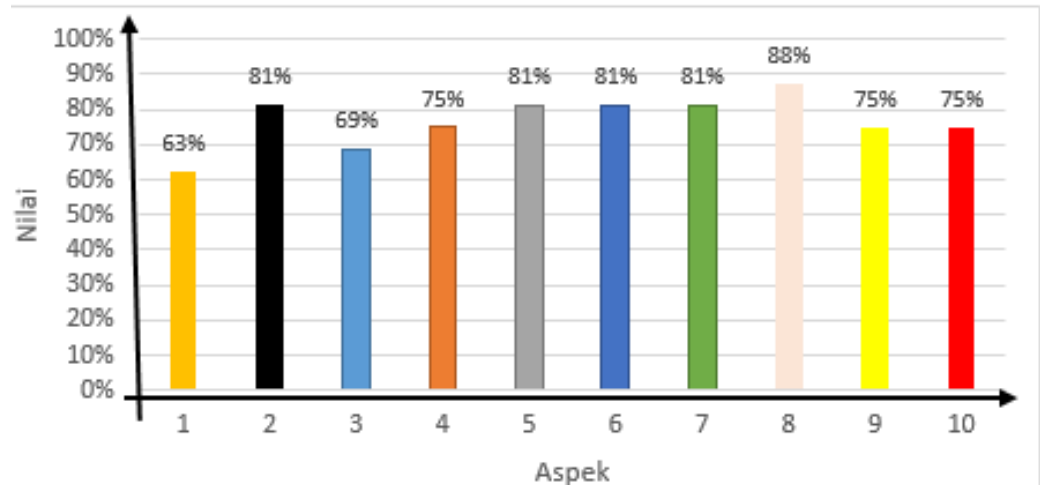

Gambar 4. Diagram Batang Keterampilan psikomotor tiap aspek untuk semua kelompok pada Pertemuan II percobaan 2

Pada pertemuan III aspek yang Aspek nomor 8 sebagai aspek tertinggu yaitu $87,50 \%$ dengan kategori baik. Faktor yang menyebabkan aspek nomor 8 memperoleh skor tertinggi karena siswa kemapuan siswa dalam menganalisis hasil percobaan sudah baik dari pada pada pertemuan 1 .

Aspek nomor 1 menjadi aspek yang memperoleh skor terendah yaitu $62,50 \%$ dengan kategori kurang baik. Faktor yang menyebabkan aspek 
nomor 1 pada RPP 2 percobaan 2 memperoleh skor terendah adalah siswa kesulitan merumuskan hipotesis karena saat memberikan pertanyaanpertanyaan yang diberikan guru mereka tidak mendengarkan dengan baik.

Hasil Pengamatan keterampilan psikomotor tiap aspek untuk semua kelompok pada pertemuan II percobaan 2 dapat dilihat pada Gambar 5.

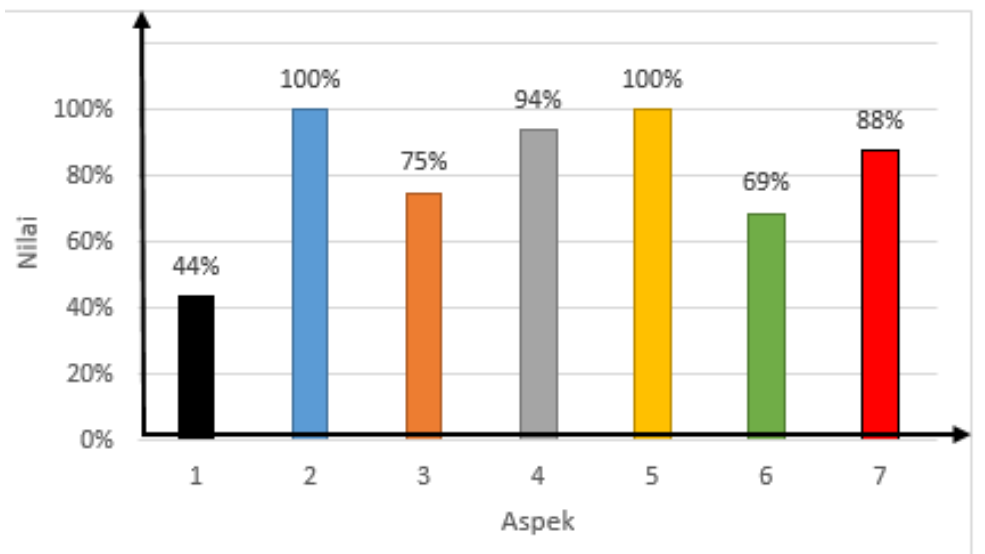

Gambar 5. Diagram Batang Keterampilan psikomotor tiap aspek untuk semua kelompok pada Pertemuan III percobaan 1

Pada pertemuan III percobaan 1 RPP 3 dengan sub materi perpindahan kalor selama pembelajaran. Aspek nomor 2 dan 5 sebagai aspek tertinggi yaitu $100 \%$ dengan kategori sanat baik. Faktor yang menyebabkan aspek nomor 2 dan 5 memperoleh skor tertinggi karena siswa sudah mengenali alat-alat di laboratorium sehingga mereka tidak mengalami Kesulitan dalam memilih alat dan bahan saat akan melakukan percobaan

Aspek nomor 1 menjadi aspek yang memperoleh skor terendah yaitu $43,75 \%$ dengan kategori kurang baik. Faktor yang menyebabkan aspek nomor 1 pada RPP 2 memperoleh skor terendah adalah siswa masih kesulitan merumuskan hipotesis dikarenakan siswa tidak mendengarkan saat guru memberi pertanyaaan-pertanyaan dia awal.

Hasil Pengamatan keterampilan psikomotor tiap aspek untuk semua kelompok pada pertemuan III percobaan 2 dapat dilihat pada Gambar 6.

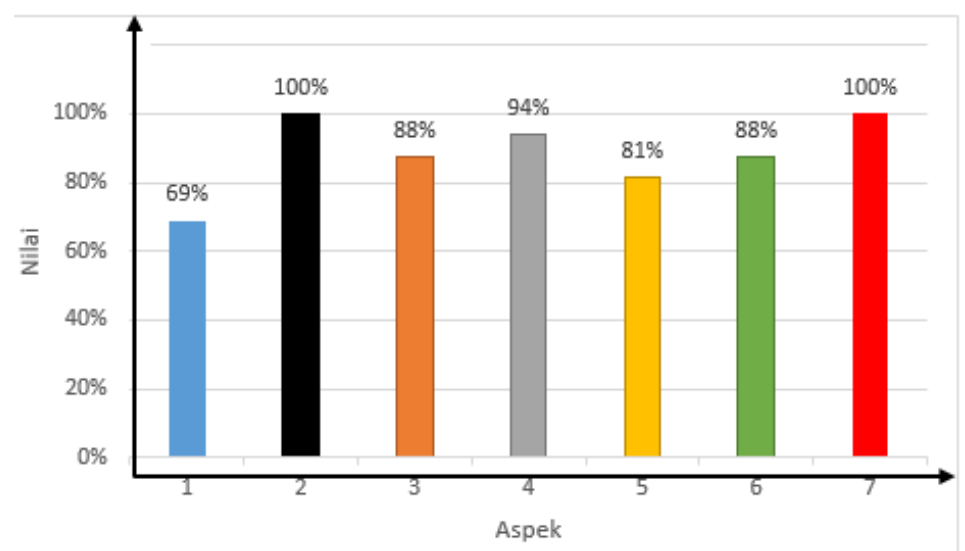

Gambar 6. Diagram Batang Keterampilan psikomotor tiap aspek untuk semua kelompok pada Pertemuan III percobaan

Pertemuan III percobaan 2 dengan sub materi perpindahan kalor selama pembelajaran. Aspek nomor 2 dan 7 sebagai aspek tertinggu yaitu $100 \%$ dengan kategori sanat baik. Faktor yang menyebabkan aspek nomor 2 dan 
7 memperoleh skor tertinggi karena siswa sudah mengenali alat-alat dilaboratorium dan siswa dapat menyimpulkan hasil percobaan karena sebagian siswa siswa sudah memahami perpindahan kalor secara konduksi sehingga mereka dapat menyimpulkan percobaan dengan benar.

Aspek nomor 1 menjadi aspek yang memperoleh skor terendah yaitu $68,75 \%$ dengan kategori kurang baik. Faktor yang menyebabkan aspek nomor 1 pada RPP 2 memperoleh skor terendah adalah siswa masih kesulitan merumuskan hipotesis.

Hasil Pengamatan keterampilan psikomotor tiap aspek untuk semua kelompok pada pertemuan III percobaan 3 dapat dilihat pada Gambar 7.

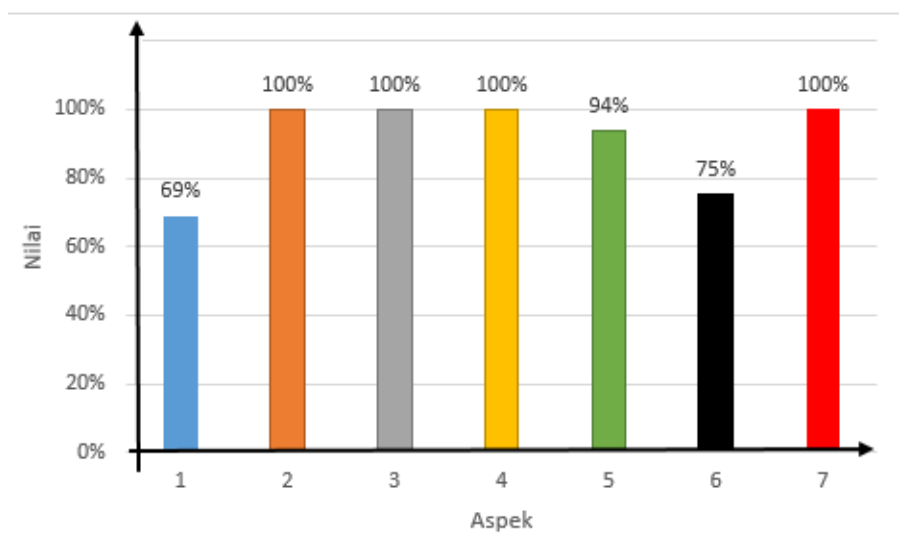

Gambar 7. Diagram Batang Keterampilan psikomotor tiap aspek untuk semua kelompok pada Pertemuan III percobaan 3

Petemuan III percobaan 3 dengan sub materi perpindahan kalor Aspek nomor 2, 3, 4 dan 7 sebagai aspek tertinggu yaitu 100\% dengan kategori sangat baik. Faktor yang menyebabkan aspek nomor 2, 3, 4 dan 7 memperoleh skor tertinggi karena siswa sudah dapat memilih alat dan bahan dengan baik, merandcang percobaan dengan baik dan benar, merakit alat dan bahan dengan baik dan benar dan dapat menyimpulkan hasil percobaan dengan benar.

Aspek nomor 1 menjadi aspek yang memperoleh skor terendah yaitu $68,75 \%$ dengan kategori kurang baik. Faktor yang menyebabkan aspek nomor 1 pada RPP 2 memperoleh skor terendah adalah siswa masih kesulitan merumuskan hipotesis.

Hasil belajar siswa diukur untuk mengetahui ketuntasan belajar secara individu, klasikal, dan TPK. Jumlah siswa kelas VII-10 SMP Negeri 2 Palangka Raya yang mengikuti tes hasil belajar (THB) kognitif materi suhu dan kalor sebanyak 32 siswa. Ketuntasan individu setelah pembelajaran dengan model pembelajaran inkuiri terbimbing di kelas VII10 diperoleh 25 siswa tuntas dan 7 siswa tidak tuntas. Ketuntasan individu setelah pembelajaran dengan model pembelajaran inkuiri terbimbing berdasarkan dapat dilihat pada diagram batang seperti pada Gambar 8 


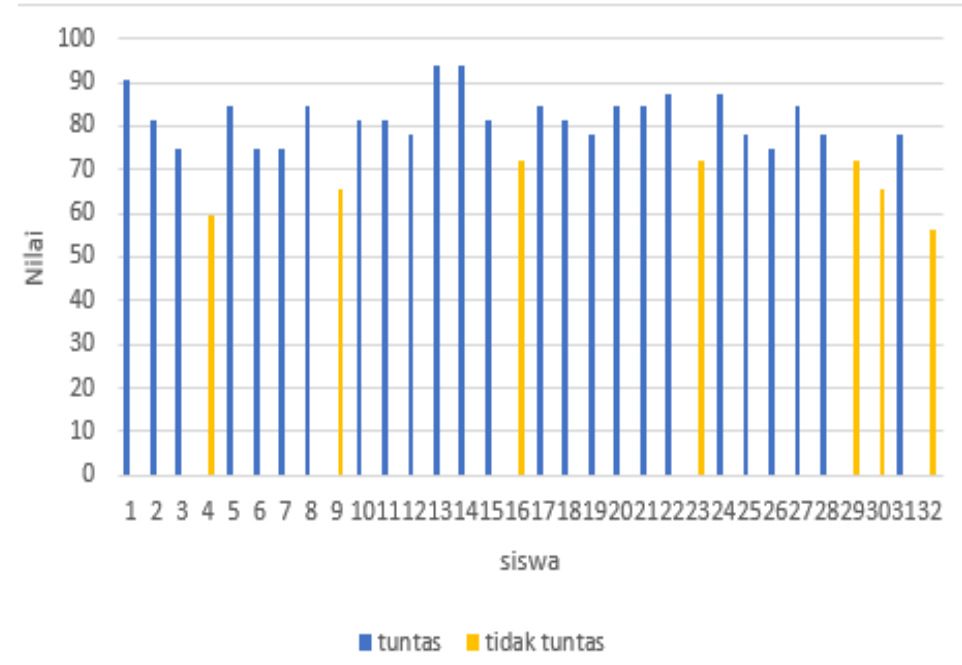

Gambar 8. Diagram Batang Ketuntasan Individu

Ketuntasan individu pada Gambar 8 menunjukkan bahwa siswa yang mendapatkan nilai tinggi lebih banyak dibandingkan yang mendapatkan nilai rendah. Hasil dari 32 siswa yang mengikuti tes hasil belajar kognitif, 25 siswa yang tuntas Siswa yang tidak tuntas sebanyak 7 siswa

Faktor-faktor yang mempengaruhi 19 siswa yang tuntas adalah sebagai berikut:

1) Tingginya nilai psikomotor kelompok menunjukkan keterampilan kelompok dalam melakukan percobaan dan menggunakan alat yang baik. Psikomotor memiliki hubungan positif dengan ketuntasan siswa, hal ini ditunjukkan dari nilai psikomotor yang tinggi sebanding dengan banyaknya siswa yang tuntas.

2) Pengetahuan siswa tentang prosedur kerja pada percobaan I, II dan III yang baik ditunjukkan dari tingginya nilai pada aspek ini di percobaan I, II dan III. Pengetahuan siswa tentang prosedur kerja menunjukkan siswa memahami proses atau alur percobaan sehingga mudah memahami garis besar materi yang dipelajari

3) Ketepatan dalam menyusun alat dan bahan percobaan pada percobaan I, II dan III. Aspek ini membangun pemahaman dasar siswa terhadap materi seperti contoh-contoh dari materi yang dipelajari berdasarkan alat yang digunakan serta persyaratan yang dibutuhkan untuk melakukan percobaan terkait materi yang diajarkan.

4) Ketepatan siswa dalam melakukan manipulasi selama percobaan yang baik ditunjukkan dari tingginya nilai pada aspek ini di percobaan I, II dan III. Aspek ini merupakan bagian penting karena paling banyak langkah yang harus dilakukan pada aspek ini dan merupakan kegiatan inti dari percobaan.

5) Mencatat hasil percobaan dan menggambar hasil percobaan yang tinggi ditunjukkan dari tingginya nilai pada aspek ini di percobaan I, II dan III. Aspek ini membantu siswa dalam memahami percobaan secara teori dan menguatkan pemahaman teori siswa setelah praktek langsung.

6) Menyimpulkan hasil percobaan yang tinggi ditunjukkan dari tingginya nilai pada aspek ini di percobaan I, II dan III.

7) Siswa dapat melakukan diskusi antara anggota kelompok dalam menyelesaikan permasalahan pada LKPD.

8) Evaluasi yang diberikan oleh pendidik kepada siswa pada kegiatan akhir pembelajaran membantu siswa dalam menghadapi soal THB. 
Berdasarkan Gambar 8 terdapat 7 siswa yang tidak tuntas, diakibatkan oleh beberapa faktor. Faktor-faktor yang mempengaruhi 7 siswa yang tidak tuntas tersebut adalah sebagai berikut.

1) Pada tahap awal percobaan masih terdapat siswa yang kurang memperhatikan prosedur kerja dan kurang mempersiapkan alat dan bahan yang digunakan dalam percobaan

2) Pada tahap inti percobaan masih terdapat siswa yang kurang teliti dan kurang perhatian dalam melakukan manipulasi selama percobaan.

3) Pada tahap akhir percobaan masih terdapat siswa yang kurang memperhatian dalam melakukan mencatat hasil percobaan pada percobaan I dan menggambarkan hasil percobaan pada percobaan I.

4) Pada tahap akhir percobaan masih terdapat siswa yang kurang dalam memberikan kesimpulan pada percobaan petemuan I, II dan III.

5) Siswa yang aktif cenderung mendominasi dalam kelompok belajar membuat ketimpangan antara siswa yang aktif dan siswa yang pasif sehingga pembelajaran menjadi tidak merata.

Ketuntasan klasikal dengan pembelajaran inkuiri terbimbing digambarkan pada diagram di bawah ini:

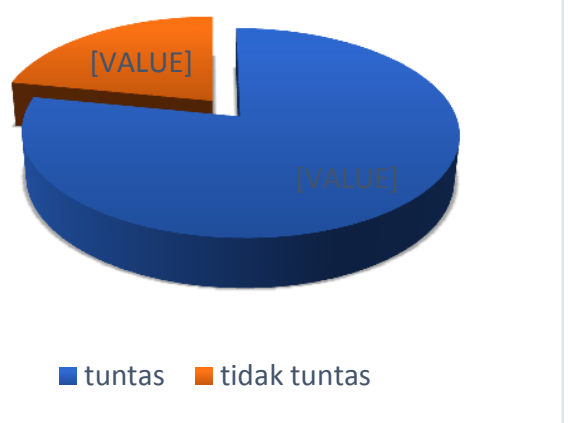

Gambar 9. Diagram Lingkaran Persentase Ketuntasan Klasikal

Gambar 9 menunjukkan besar persentase ketuntasan klasikal yang dicapai sebesar 78,12\%, hal ini menunjukkan bahwa dengan menggunakan model pembelajaran inkuiri terbimbing mampu memenuhi syarat ketuntasan klasikal minimum yaitu sebesar $\geq 75 \%$. Ketuntasan klasikal dipengaruhi oleh ketuntasan individu sehingga ketuntasan klasikal yang tuntas menunjukkan bahwa banyak siswa yang tuntas dan sedikit siswa yang tidak tuntas. Hal ini dikarenakan banyak siswa yang tuntas sebanyak 25 siswa dan 7 siswa tidak tuntas dari 32 siswa kelas VII-10 yang mengikuti ujian.

Ketuntasan TPK setelah menerapkan model pembelajaran inuiri terbimbing pada materi suhu dan kalor secara sederhana dapat dilihat pada Gambar 10 berikut: 


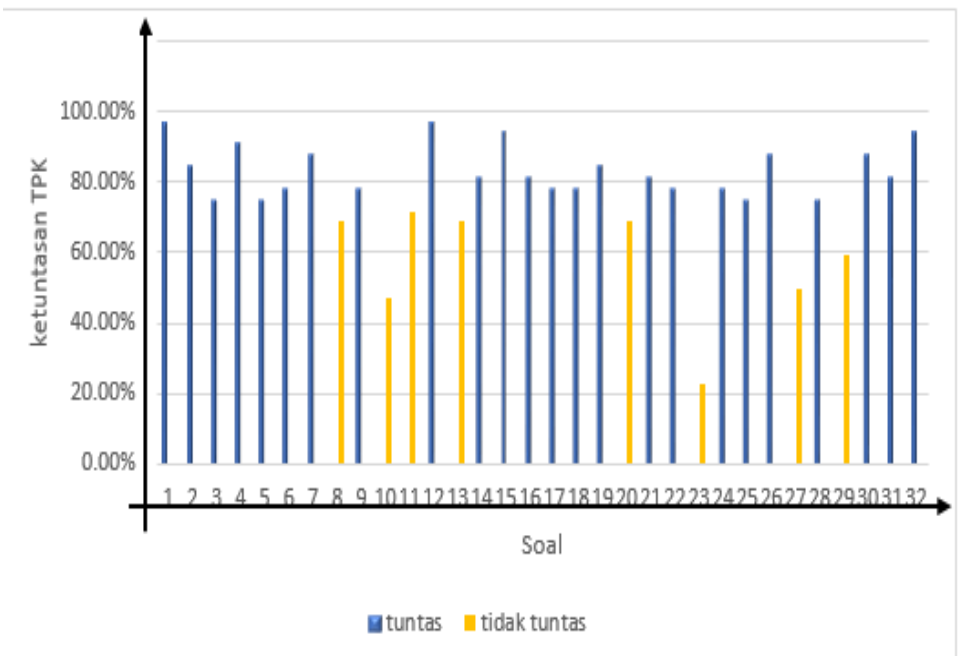

Gambar 10. Diagram Batang Persentase Ketuntasan TPK

Berdasarkan Gambar 10, dari 32 TPK yang terdapat 24 TPK yang tuntas dan 8 TPK tidak tuntas. Dari 32 TPK terdapat 24 TPK yang tuntas yang terdiri dari 12 TPK aspek pengetahuan $\left(\mathrm{C}_{1}\right), 11$ TPK aspek pemahaman $\left(\mathrm{C}_{2}\right), 6$ TPK aspek penerapan/aplikasi $\left(\mathrm{C}_{3}\right) 2$ TPK aspek analisis $\left(\mathrm{C}_{4}\right)$ dan 1 TPK aspek kreasi $\left(\mathrm{C}_{6}\right)$. Persentase TPK yang berhasil dituntaskan sebesar 75\%. TPK yang tidak tuntas terdapat 8 TPK, yaitu4 TPK aspek pemahaman $\left(\mathrm{C}_{2}\right)$ dan 2 TPK aspek penerapan/aplikasi $\left(\mathrm{C}_{3}\right)$, dan 2 TPK aspek analisis $\left(\mathrm{C}_{4}\right)$ persentase TPK yang tidak tuntas sebesar $25 \%$.

\section{SIMPULAN}

Berdasarkan data dan analisis hasil penelitian yang telah dilakukan tentang pembelajaran menggunakan model inkuiri terbimbing pada materi suhu dan kalor, dapat disimpulkan bahwa:

1. Hasil keteramilan psikomotor per aspek pada RPP I nilai tertinggi yaitu aspek 7 sebesar 100\%, RPP II percobaan 1 tertinggi yaitu aspek 1 dan 5 sebesar 93,75\%, RPP percobaan 2 nilai tertinggi yaitu aspek 8 sebesar 87,5\%, RPP III percobaan 1 yaitu aspek 1 dan 5 sebesar 100\%, RPP III percobaan 2 nilai tertinggi yaitu aspek 1 dan 7 sebesar 100\%, RPP III percobaan 3 nilai tertinggi yaitu aspek 1, 3, 4, dan 7 sebesar $100 \%$. Aspek terendah yaitu aspek 2 pada RPP III percobaan 1 sebesar $43,75 \%$.

2. Ketuntasan hasil belajar kognitif siswa secara individu dari 32 siswa diperoleh 25 siswa tuntas dan 7 siswa tidak tuntas. Ketuntasan klasikal siswa sebesar 78,12\% tuntas dan mencapai standar ketuntasan klasikal yang ditetapkan yaitu $\geq 75 \%$. TPK yang tuntas sebanyak 24 dari 32 TPK dengan persentase TPK yang tuntas $75 \%$.

\section{REFERENSI}

Jufri, A. Wahab. (2013). Belajar dan Pembelajaran Sains. Bandung: Pustaka Reka Cipta.

Jauhar, Muhammad,2011. Implementasi Paikem Dari Behavioristik Sampai Kontruktivistik. Jakarta: Prestasi Pustaka Publiser

Kunandar. (2014). Penilaian Autentik Hasi Belajar Siswa Berdasarkan Kurikulum 2013. Jakarta: PT. Raja Grafindo Persada

Supartiningrum, Jamil. (2013). Strategi Pembelajaran Teori dan Aplikasi. Yogyakarta: ARRozz Media

Sanjaya, Ade (2011). Model-model Pembelajaran. Jakarta: Bumi Aksara. 
Sugiyono. (2012). Metode Penelitian Kuantitatif, Kualitatif Dan R\&D. Bandung: Alfabeta.

Trianto. (2010). Mendesain Model Pembelajaran Inovatif-Progresif. Jakarta: Kencana Prenada Group. 